\title{
A LABORATORY SCALE ANALYSIS OF GREYWATER USING DRAWER COMPACTED SAND FILTER
}

\author{
Prajakta R. Pazare $^{1}$ and Ms. C. S. Waghmare ${ }^{2}$ \\ ${ }^{1}$ PG Student Environmental Engineering, ${ }^{2}$ Assistant Professor \\ ${ }^{1,2}$ Department of Civil Engineering \\ ${ }^{1}$ Yeshwantrao Chavan College of Engineering, Nagpur
}

\begin{abstract}
Water is an important natural resource to maintain human and animal life. Due to rapid industrialization, development and increasing population there is an increase in demand of water. So we need to search for alternatives to reduce the consumption of freshwater. One of such alternative is greywater treatment. Sand filtration has been considered as one of the effective and economical methods for water and wastewater treatment. One of such sand filtration technique is Drawer Compacted Sand Filter (DCSF), which is a modified design for sand filter. This paper presents the performance analysis of Drawer Compacted Sand Filter(DCSF), carried out on the basis of its first cycle. It was found that DCSF is efficient in removal of COD, TSS and turbidity with removal percentage of $95.83 \%, 80.76 \%$ and $89.71 \%$ respectively. It is easy to maintain, flexible, requires less area, effective and less expensive.
\end{abstract}

Key Words : Synthetic greywater, Drawer Compacted Sand Filter.

\section{Introduction}

Water is a very important and an essential need of every human being and animal to survive. The area of earth's surface covered with water is about $70 \%$, but the quantity of fresh water is very less. The distribution of water over the globe is uneven; the oceans contains about $97 \%$ of total amount of water present on earth, freshwater's share is only $3 \%$, in which $79 \%$ is trapped in ice caps and glaciers, groundwater is $20 \%$ and accessible surface freshwater is only $1 \%$. The accessible surface water has $52 \%$ of its water in lakes, $1 \%$ in rivers, $1 \%$ in living organisms, $8 \%$ as water vapours and remaining $38 \%$ as soil moisture [1]. From this we can observe that amount of freshwater available is very less and it is decreasing dayby-day due to human activities. Due to rapid industrialization, development and increasing population there is an increase in demand of water. According to World Water Development Report 2015, it is expected that demand of water for manufacturing will increase globally upto 400 percent between 2000 and 2050 . Around 700 million people in 43 countries suffer today from water scarcity. It is estimated that by 2025 , twothirds of the world's population could be living under water stressed conditions and 1.8 billion people will be living in regions with absolute water scarcity [8].So we need to search for alternatives to reduce the consumption of freshwater. One of such alternative is greywater $(\mathrm{GW})$ treatment. Greywater can be defined as any domestic waste water produced, excluding sewage. In other words residential greywater can be defined as a mixture of wastewater discharges from household including kitchen sinks, laundary waste water, bathroom sinks and bathtubs[6]. The quantity of greywater is around $60 \%$ $70 \%$ of total wastewater produced in a day [5]. The benefits of greywater recycling includes, less fresh water extraction, less impact on septic tank and treatment plant infrastructure, reduced energy use, ground water recharge, increased plant growth, greater quality of surface water, protection of ground water, maintain soil fertility, protection of land and vegetation and protection of the community against possible disease transmission [3]. There are various methods by which greywater can be treated. Sand filtration has been considered as one of the effective and economical methods for water and wastewater treatment since ancient times. One of such sand filtration technique is Drawer Compacted Sand Filter (DCSF), which is a modified design for sand filter in which sand layer is broken down into several layers. The depth of these sand layers may be 5 to $10 \mathrm{~cm}$ each and placed in movable drawers separated by 5 to $10 \mathrm{~cm}$ space each. As the drawers are spaced at distance oxygen movement is facilitated, which maintain aerobic condition, no anoxic conditions, thus no unpleasant odors [9]. It is easy to maintain, flexible, requires less area, effective and less expensive.

\section{Materials Used in Study}

\section{A. Sand and Gravel}

In DCSF, sand was used as a major filtering medium. Sand could remove large extend of impurities from water. Three draws of DCSF were filled with different grades of sand. The sand was obtained from YCCE's Concrete lab, that is brought from Bhandara district. The gravels were 
obtained from this stock sand. The sand and gravel were sieved according to the sieve analysis method and different grades of sand and gravel were obtained.

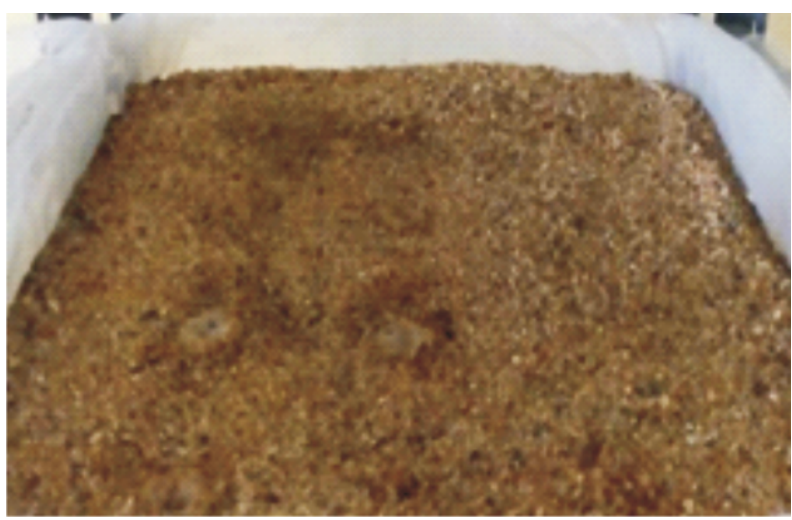

Fig. 1 : Sand

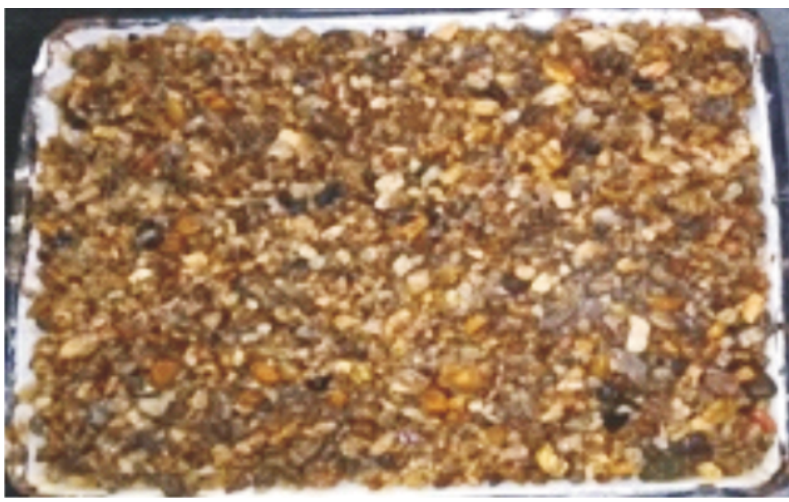

Fig. 2 : Gravel

\section{B. Coconut shell activated charcoal}

Charcoal that is processed to increase its porosity and surface area to increase its adsorption capacity is called as activated charcoal [10]. In DCSF, coconut shell activated charcoal which is in granular form has been used.

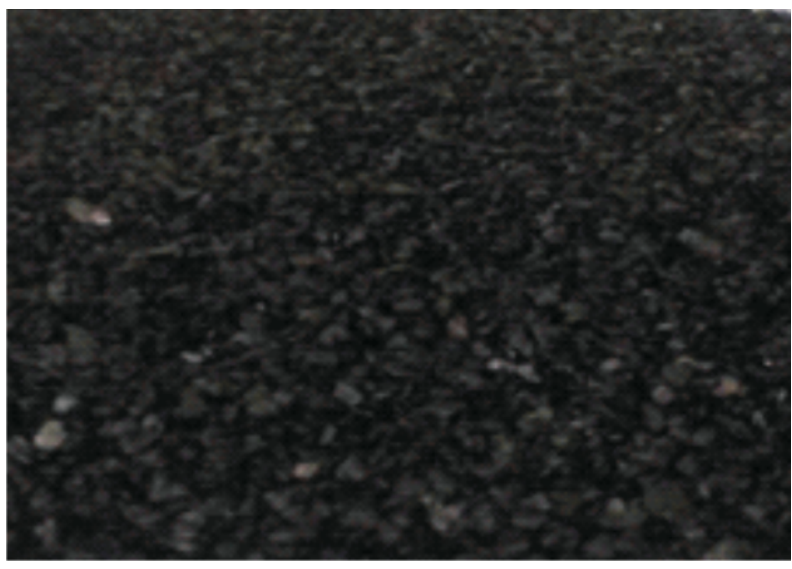

Fig. 3 : Coconut shell activated charcoal

\section{Methodology Adopted}

A. Prepration of synthetic greywater and Characteristics The characteristics of real greywater were observed and synthetic greywater was prepared. The composition of synthetic greywater prepared in lab is shown in table 1 and characteristics of this synthetic greywater after testing are shown in table 2 .

Table 1

Composition of Synthetic Greywater

\begin{tabular}{|l|l|}
\hline Component & Concentration $(\mathrm{g} / \mathrm{l})$ \\
\hline Tap water & 1 lit \\
\hline Washing powder & $0.16 \mathrm{~g} / 1$ \\
\hline Coconut oil & $0.1 \mathrm{~g} / 1$ \\
\hline Dish washing solution & $0.16 \mathrm{~g} / 1$ \\
\hline Handwash & $0.16 \mathrm{~g} / 1$ \\
\hline Body wash & $0.16 \mathrm{~g} / 1$ \\
\hline
\end{tabular}

Table 2

Characteristics of synthetic greywater

\begin{tabular}{|l|l|l|}
\hline Parameter & Unit & Concentration \\
\hline COD & $\mathrm{mg} / \mathrm{l}$ & 240 \\
\hline TSS & $\mathrm{mg} / 1$ & 78 \\
\hline TDS & $\mathrm{mg} / \mathrm{l}$ & 628.1 \\
\hline Turbidity & $\mathrm{NTU}$ & 24.3 \\
\hline Conductivity & $\mu \mathrm{S} / \mathrm{ppt}$ & 1.362 \\
\hline $\mathrm{pH}$ & - & 8.5 \\
\hline Hardness & $\mathrm{mg} / \mathrm{l}$ & 168 \\
\hline
\end{tabular}

\section{B. Experimental Setup}

a) Drawer Compacted Sand Filter (DCSF) Fabrication:- A DCSF unit of iron framework was fabricated and seven plastic drawers with dimensions of $36 \mathrm{~cm} \times 25.5$

$\mathrm{cm} \times 7 \mathrm{~cm}$ were obtained and placed on the frame. Out of the seven plastic drawers one drawer was used for distribution of synthetic greywater over the gravel bed uniformly. It was connected to a storage container which contains synthetic greywater, placed besides DCSF unit. 


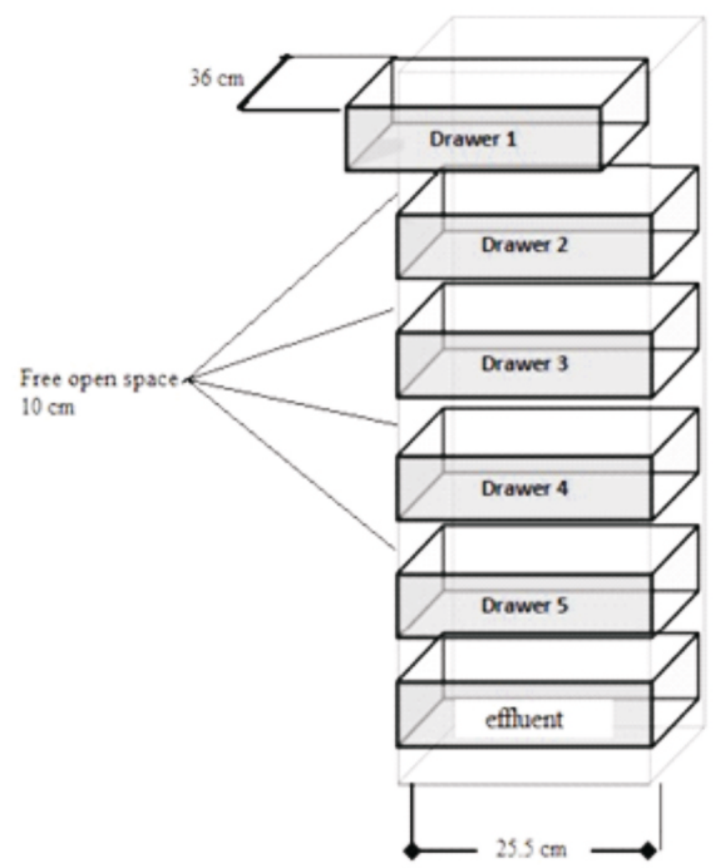

Fig. 4 : Schematic diagram experimental set up

b) Design Parameters of the Laboratory DCSF :- For lab study, the drawers used have dimensions $36 \mathrm{~cm} \times 25.5$ $\mathrm{cm} \times 7 \mathrm{~cm}$ based on the availability.

Table 3

Design Parameters of the Laboratory DCSF

\begin{tabular}{|l|l|}
\hline Drawers & Filter medium \\
\hline Drawer 1 & Distribution of Synthetic GW \\
\hline Drawer 2 & Gravels; effective size $=4.75$ \\
\hline Drawer 3 & Sand; effective size $=2.36$ \\
\hline Drawer 4 & Sand; effective size $=1.3$ \\
\hline Drawer 5 & Sand; effective size $=0.6$ \\
\hline Drawer 6 & Activated charcoal \\
\hline Drawer 7 & Collection of effluent \\
\hline Depth of media & 5 cm in each drawer \\
\hline $\begin{array}{l}\text { No. and size of Perforation in each } \\
\text { drawer }\end{array}$ & 12 and $3 \mathrm{~mm}$ \\
\hline
\end{tabular}

C. Operating conditions and procedures:- Drawer compacted sand filter with gravel, sand and activated charcoal were fed with synthetic grey water. It was operated under room temperature and after each treatment the effluent was tested for $\mathrm{pH}, \mathrm{COD}$, Hardness, turbidity, TSS, TDS and conductivity.

D. Mechanism of treatment in DCSF :- The synthetic grey water was pumped using a submersible pump and transferred via distribution tray placed over the upper surface of the gravel layer of drawer number 2 . The water then percolates through the filtering media placed in drawer number 2 to drawer 3 and one by one passes through each filtering media in all drawers at a flow rate of
$4 \mathrm{lit} / \mathrm{hr}$. The treated greywater thus obtained from the last drawer is then collected and tested.

\section{Results}

Performance analysis of drawer compacted sand filter was carried out and the results are reported as below.

Table 4

Experimental data of DCSF

\begin{tabular}{|l|l|l|l|l|}
\hline Parameter & \multicolumn{1}{|c|}{ Unit } & $\begin{array}{c}\text { Influent } \\
\text { Concentration }\end{array}$ & $\begin{array}{c}\text { Effluent } \\
\text { Concentration }\end{array}$ & $\begin{array}{c}\% \\
\text { Removal } \\
\text { Efficiency }\end{array}$ \\
\hline COD & $\mathrm{mg} / \mathrm{l}$ & 240 & 10 & $95.83 \%$ \\
\hline $\mathrm{TSS}$ & $\mathrm{mg} / \mathrm{l}$ & 78 & 15 & 80.76 \\
\hline TDS & $\mathrm{mg} / \mathrm{l}$ & 628.1 & 554.4 & $11.73 \%$ \\
\hline Turbidity & $\mathrm{NTU}$ & 24.3 & 2.5 & $89.71 \%$ \\
\hline $\begin{array}{l}\text { Conductivit } \\
\mathrm{y}\end{array}$ & $\mu \mathrm{S} / \mathrm{ppt}$ & 1.362 & 1.135 & $20 \%$ \\
\hline $\mathrm{pH}$ & - & 8.5 & 8.5 & - \\
\hline Hardness & $\mathrm{mg} / \mathrm{l}$ & 168 & 152 & $9.52 \%$ \\
\hline
\end{tabular}

High COD removal efficiency can be seen in DCSF. Because, DCSF works fully under aerobic condition as the sand layers are divided into several layers it gives air space between each layer, which allows oxygen to diffuse easily and thus enhance the treatment of greywater and increase the treatment efficiency.

Aerobic bacteria requires oxygen for their survival. They use this oxygen in the metabolism of biodegradable components, inactivation and consumption of pathogens. The decrease in this quantity of oxygen will give rise to anaerobic condition along with the production of ammonia, hydrogen sulphide and other substances which produce bad odors [2].

\section{Conclusion}

From the above analysis, carried out on the basis of first cycle of DCSF it was found that DCSF is efficient in removal of COD,TSS and turbidity with removal percentage of $95.83 \%, 80.76 \%$ and $89.71 \%$ respectively. With further analysis better results can be obtained. DCSF is easy to maintain, flexible, requires less area, effective and less expensive. This paper concludes that, as land footprints of DCSF is small it is suitable for dense urban areas where land availability is a huge problem and as it is convenient to use and requires low maintenance, it can be used by wide range of people without any problem.

\section{Future Scope}

This paper provides preliminary perspective of DCSF. Further investigation is required to be carried out to check the performance of DCSF by using different media depth, different filter media with different sizes, responses to different hydraulic and organic loads and finding out the mechanism of water movement through each drawer and also its impact on the bacterial removal mechanism. 


\section{References}

[1] http://earth.rice.edu/mtpe/hydro/hydrosphere/ hot/freshwater/0water_c hart.html ; Earth Forum, Houston Museum of Natural Science

[2] Prof.Neethu John, Abhijith G, CijiB,Haripriya M, Jivic J Panackal, SijithaSidhan (2017), "Modified Drawer Compacted Sand Filter",IRJET, e-ISSN: 2395 -0056 Volume: 04 Issue: 03 | Mar -2017 www.irjet.net p-ISSN: 2395-0072

[3] Bessy John, Bindu.G, Associate Professor (2017), "Greywater Treatment by Drawer Compacted Sand Filter with Silver Coated Sand", IJSTE |Volume3|Issue 10|April2017 ISSN (online): 2349$784 \mathrm{X}$

[4] Dr. B. M. Sadashiva Murthy et al. (2016), "Greywater Treatment \& Reuse: A Technological Review”, GJRA,Volume-5,Issue-3, March 2016, ISSN No 2277-8160.

[5] Assayed A., Chenoweth J., \&Pedley S. (2015): "Assessing the efficiency of an innovative method for onsite greywater treatment: Drawer compacted sand filter - A case study in Jordan". Ecological Engineering, 81:525-533

[6] SandhyaPushkar Singhet al., (2015), "A Study on Greywater Treatment Processes: A Review", IJSRD -| Vol. 3, Issue 08, 2015 | ISSN (online): 2321-0613
[7] Golda A. Edwin et.al. (2014), "Characterization of domestic gray water from point source to determine the potential for urban residential reuse: a short review", Appl Water Sci (2014) 4:39-49 DOI 10.1007/s13201013-0128-8.

[8] http://www.un.org/waterforlifedecade/ scarcity. shtml United Nations Department Of Economic and social affairs (UNDESA),2014.

[9] Almoayied Assayed (2013), "Drawer Compacted Sand Filter: A new and innovative design for onsite wastewater treatment.", University of Surrey, Centre for Environmental Strategy Guildford GU2 $7 \mathrm{XH}$, United Kingdom

[10] https://en.wikipedia.org/wiki/Activated_carbon

[11] National environmental engineering research institute (NEERI), (2007) "greywater reuse in rural schools" wise water management, and guidance manual. 